\title{
Characterization of sunflower husk ashes and feasibility analysis of their incorporation in soil and clay mixtures for ceramics
}

\author{
N. E. Quaranta ${ }^{1,2}$, G. G. Pelozo ${ }^{1}$, A. Cesari $^{1}$ \& A. A. Cristóbal ${ }^{3}$ \\ ${ }^{I}$ Environmental Studies Group, San Nicolás Regional Faculty, \\ National Technological University, Argentina \\ ${ }^{2}$ CIC, La Plata, Argentina \\ ${ }^{3}$ Ceramics Group, INTEMA-CONICET, \\ Mar del Plata National University, Argentina
}

\begin{abstract}
The aim of this work is to study ashes from the combustion of sunflower husks in order to determine their environmental suitability for reuse as a structural filler or as an aggregate in clay mixtures for the manufacture of ceramics. Various characterization techniques were used, such as optical and electronic microscopy, $\mathrm{X}$-ray electron dispersive analysis, X-ray diffraction, analysis of particle size distribution, soluble solids, conductivity, $\mathrm{pH}$, leaching test and ecotoxicity, among others. The results of chemical analysis show that the main elements are $\mathrm{Mg}, \mathrm{Ca}$, and $\mathrm{P}$. The conductivity and $\mathrm{pH}$ values after $2 \mathrm{~h}$ of stirring in distilled water are $17.11 \mathrm{mS}$ and 11.46, respectively. Results from analysis of the leaching test determine that none of the measured values in the ashes exceed the limits established by law 24051 (Argentina) on hazardous waste. Regarding the ecotoxicity analysis, it is observed that sunflower husk ashes inhibit the growth of seedlings at the studied concentrations. It can be concluded that it is not convenient to use the ashes as soil filler because it would produce alkaline soil, transferring a large amount of electrolytes, and producing negative effects on the development of many species that need acid or slightly alkaline soil. From the experimental results and the analysis of the equilibrium diagrams of the major oxides of claywaste mixtures, the theoretical sintering temperature was determined. It shows that it is feasible to incorporate up to $20 \%$ of this waste material holding sintering temperatures commonly used in the ceramic industry $\left(1050^{\circ} \mathrm{C}\right)$. For higher
\end{abstract}


percentages, the sintering temperatures of the compact bodies increase, making incorporation difficult and costly.

Keywords: sunflower husk ashes, soils, ceramics.

\section{Introduction}

In the production process of sunflower oil, the seeds are introduced in a first stage into a process of grinding or shaking. Then the seeds with a small volume of shells, which are needed to achieve adequate protein content, resulting in the production of oil by pressing. The shells discarded in the first process step are used directly as fuel in boilers, generating ashes accumulation in the base of this. These produced ashes are studied in this work. This residue is located within the so-called biomass ashes because, according to the biomass definition, it comes from waste and/or residues of biological origin from agriculture and used as fuel.

In relation to sunflower husk ash has been found to be used for manufacturing ceramic products incorporating crushed glass up to $50 \%$ [1], with particles smaller than $75 \mu \mathrm{m}$ for mixtures with $30 \%, 40 \%$ and $50 \%$ of glass and optimal sintering temperatures of $1400^{\circ} \mathrm{C}, 1300^{\circ} \mathrm{C}$ and $1250^{\circ} \mathrm{C}$ respectively. Ceramics were also obtained with the addition of ashes from other biomass such as residues from wood felling and processing [2]. In this case, the authors studied as added in clay mixtures in amounts from $10 \%$ to $50 \%$. Samples were compacted to $54,5 \mathrm{MPa}$ forming solid bricks of $30 \mathrm{~mm} \times 10 \mathrm{~mm} \times 60 \mathrm{~mm}$ size and heating at $950^{\circ} \mathrm{C}$ without additives. The pieces until $20 \%$ of ashes are within the limits established by European standards in terms of mechanical properties.

Ashes of sugarcane for producing vitreous ceramics where silicates constituted the major crystalline phases were also used [3]. The mixtures were prepared by mixing ashes $(40-45 \%)$, limestone $(45-50 \%)$ and potassium carbonate $(10 \%)$ as flux. The authors concluded that at temperatures below $900^{\circ} \mathrm{C}$ it is possible to obtain vitreous ceramics.

An initial study on the manufacture of bricks was made with ashes from biomass of olive oil production [4]. Bricks were obtained by conventional moulding methods using until $20 \%$ ash, without special additives. The sintering temperature used in this case is in the range $1000^{\circ} \mathrm{C}-1100^{\circ} \mathrm{C}$.

The biomass ashes mentioned before are widely used for the manufacture of cement due to its grain size and chemical composition with high contents of $\mathrm{SiO}_{2}$ and $\mathrm{CaO}$ [5-7]. The rice husks were also studied with this purpose [8] and for incorporation as filler in bituminous mixtures [9].

The use of rice husk ash and cement for stabilizing soils by compaction resistance and X-ray diffraction was studied [10]. Test results show that $6-8 \%$ of cement and 15-20\% ashes are optimal amounts for improving the properties of soils. Due to the high content of micronutrients, forest and agro industry ashes were studied as a soil amendment [11]. Different tests of leach to evaluate the leaching of these ashes were used. The results of these tests show that in various biomass agricultural ashes, $\mathrm{Mn}, \mathrm{Ni}$ and $\mathrm{Zn}$ have the highest concentrations. However, none of these extracts values exceed allowed limits for water soluble elements. 
In this work, the ashes from the combustion of sunflower husk were studied in order to determine its environmental suitability for reuse as soils filler or added in clay mixtures for the manufacture of ceramics.

\section{Experimental}

The physicochemical characteristics of sunflower husk ashes were determined using different techniques: optical microscopy (OM), scanning electron microscopy (SEM), energy dispersive analysis of X-ray (EDS), X-ray diffraction (XRD), analysis of particle size distribution, soluble solids, conductivity, $\mathrm{pH}$, leachate analysis, ecotoxicity, among others.

Optical observations were performed using the Zeiss-Axiotech Donpisha 3CCD camera equipment.

For SEM-EDS analysis SEM Philips 515 equipment, with energy dispersive analyser (EDAX-Phoenix) was used.

Diagrams of X-ray diffraction were obtained with a PANalytical X'Pert PRO Radiation $\mathrm{CuK} \alpha(\lambda=1,5406 \mathrm{~nm})$, at $40 \mathrm{Kv}$ and $40 \mathrm{~mA}$.

FTIR spectra were obtained with a Nicolet 6700, Thermo Electron Corp. equipment, in attenuated total reflectance - ATR mode.

The size distribution of particles larger than 75 microns was determined using a vibrating table with overlapping sieves according to standard ASTM C 92-76, while particles smaller than 75 microns were tested by a sedimentation process according to ASTM D 422-63.

The conductivity and $\mathrm{pH}$ of the residue was measured with equipment-SPER SCIENTIFIC Model 860,032 and Altronix TPX-III, respectively, after two hours of stirring at room temperature in a residual proportion of $10 \mathrm{~g}$ of powder in $100 \mathrm{ml}$ of demineralised water. Soluble solids were obtained in the same proportions with stirring and temperature (about $100^{\circ} \mathrm{C}$ ) to promote solubilisation. Chemical composition of the solids obtained after filtering the solution and evaporating the water was analysed by means of EDS.

The leachate analysis of the residue was performed according to norm EPA 1310 analysing heavy metals in the leaching liquid by plasma emission spectrometry with a Perkin Elmer ICP Optima 3100XL.

The ecotoxicity analyses were carried out by adapting the standard IRAM 29114: 2008. The test is performed by placing two filter papers inside a Petri dish, these filter papers are saturated with $3.5 \mathrm{ml}$ of test dilution. These dilutions are obtained from an aqueous extract of the samples of ashes in relation ash:distilled water equal to 1:4, stirring for 2 hours, and subsequent filtering. Twenty seeds of rye grass species are placed in each dish and covered. Dilutions of $25 \%, 50 \%$ and $100 \%$ of the original aqueous extract, for 120 hours at $24^{\circ} \mathrm{C}$, were tested. A test with untreated solid residue was also performed for comparative purposes, placing a layer of it below the filter papers. Reference controls are carried out with distilled water. Three replicates of each concentration were performed. Once the exposure period was finished, the inhibition of the seed root elongation (RI) was determined as percentage in relation to reference sample (distilled water). 
To determine the feasibility of reusing sunflower husk ashes as aggregate in clay mixtures for the production of ceramic materials, Casagrande method (ASTM D4318) to study the plastic characteristics of the mixtures was used. The test was performed with mixtures of clay and residue, in the following percentages $10 \%$, $20 \%, 30 \%$ and $40 \%$ of ashes. Besides, theoretical sintering temperatures were established by using the equilibrium ternary diagrams.

\section{Results and discussion}

The chemical composition of sunflower husk ashes, determined by energy dispersive analysis (EDS) is presented in table 1. Carbon and oxygen values are included. In this table it is possible to observe that the highest percentage elements besides the $\mathrm{C}$ and $\mathrm{O}$ are $\mathrm{Mg}$ and $\mathrm{Ca}$.

The microscopic appearance of the ash sample is shown in Figures 1 and 2. In Figure 1 micrographs by optical microscopy (OM) are presented, where the morphology and colouring of the particles after combustion are observed. The bigger particles are actually agglomerates of the smaller ones and they present grayish colorations.

Table 1: $\quad$ EDS analysis of sunflower husk ashes.

\begin{tabular}{|cc|}
\hline Element & Weight [\%] \\
\hline $\mathrm{C}$ & 21.4 \\
\hline $\mathrm{O}$ & 40.5 \\
\hline $\mathrm{Mg}$ & 15.6 \\
\hline $\mathrm{Al}$ & 1.1 \\
\hline $\mathrm{Si}$ & 4.0 \\
\hline $\mathrm{P}$ & 4.8 \\
\hline $\mathrm{Cl}$ & 0.1 \\
\hline $\mathrm{K}$ & 4.6 \\
\hline $\mathrm{Ca}$ & 7.9 \\
\hline
\end{tabular}

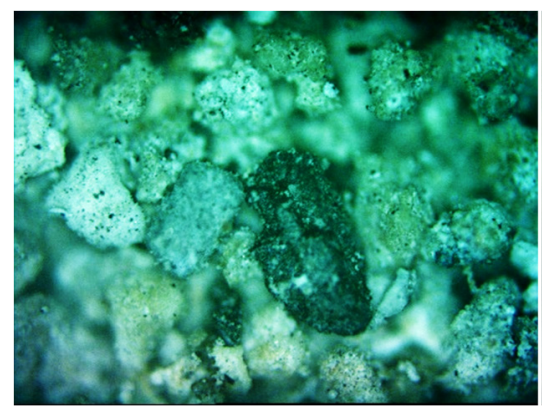

(a)

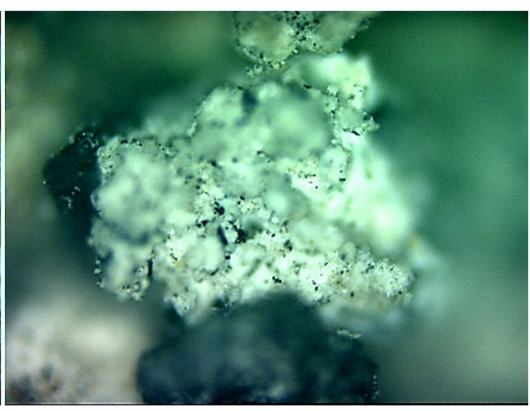

(b)

Figure 1: OM micrographs of the ashes: (a) 50x; (b) 100x. 


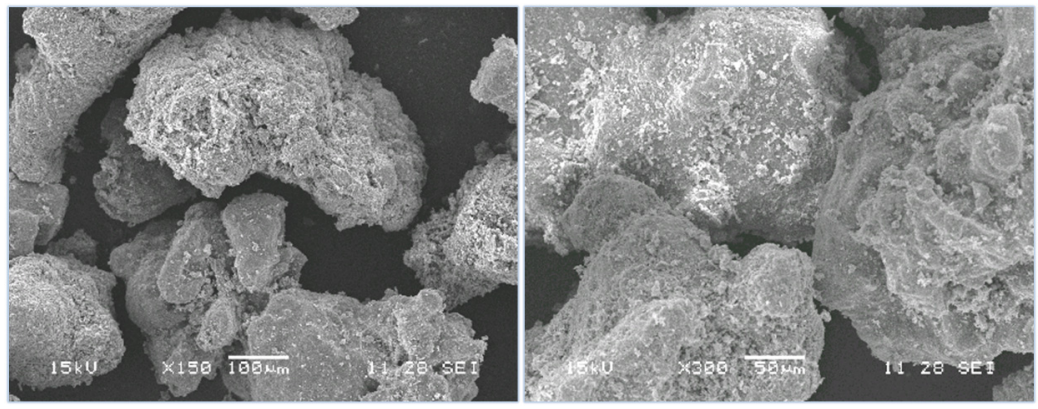

Figure 2: $\quad$ SEM images of the ashes.

In Figure 2, the different particle sizes are observed by SEM images. Most of the particles have sizes greater than 500 microns. Figure 3 shows the results of particle size distribution analysed by vibrating method for particles larger than 75 microns, and by sedimentation method for particles smaller than this value.

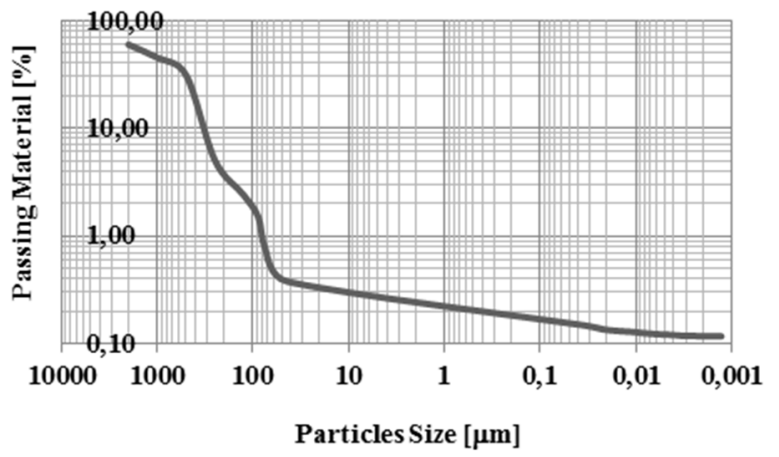

Figure 3: Particle size distribution of the sample of sunflower husk ashes.

Taking into account the significant percentage of big particles observed in this sample (Figure 3), if these materials were used for forming ceramic pieces, a previous grinding and grading separation would be necessary.

The X-ray diffraction patterns of the ashes are shown in Figure 4. The main phases present are $\mathrm{MgCa}\left(\mathrm{CO}_{3}\right)_{2}$ (pdf 831766), $\mathrm{MgO}$ (pdf 870653), $\mathrm{CaSiO}_{3}$ (pdf 840654), $\mathrm{Mg}_{2} \mathrm{P}_{2} \mathrm{O}_{7}$ (pdf 751055) and $\mathrm{K}_{2} \mathrm{Si}_{4} \mathrm{O}_{9}$ (pdf 751646).

Fourier transform infrared spectroscopy (FTIR) for qualitative analysis of present compounds and in order to identify the functional groups in the ashes sample has been used. The obtained FTIR spectrum, using ATR mode, in the frequency range of $500-4000 \mathrm{~cm}^{-1}$, is shown in Figure 5. It is possible to distinguish oscillations in the frequency range of 3200-2800 like a broad signal of low intensity vibration which can be attributed to the $\mathrm{CH}$ group. The two lowintensity peaks observed at 2366 and $2338 \mathrm{~cm}^{-1}$ are typical of the $\mathrm{O}=\mathrm{C}=\mathrm{O}$ asymmetric stretching. The spectrum shows a very pronounced vibration in the 
frequency values of approximately $1400 \mathrm{~cm}^{-1}$ which has been assigned to $\mathrm{CO}_{3}=$ group. Another intensive peak is observed at approximately $1100 \mathrm{~cm}^{-1}$, corresponding to $\mathrm{PO}_{4}$ anion functional group. Finally, some less-pronounced vibration peaks characteristic to $\mathrm{CaO}$ and $\mathrm{MgO}$ in the absorption frequency range of $900-500 \mathrm{~cm}^{-1}$ are also detected. Similar results for FTIR analysis of sunflower husk ashes have been presented by other authors [12].

$\mathrm{pH}$ and conductivity analysis in the residue at room temperature and after 2 hours stirring were determined. The values obtained were 11.46 and $17.11 \mathrm{mS}$

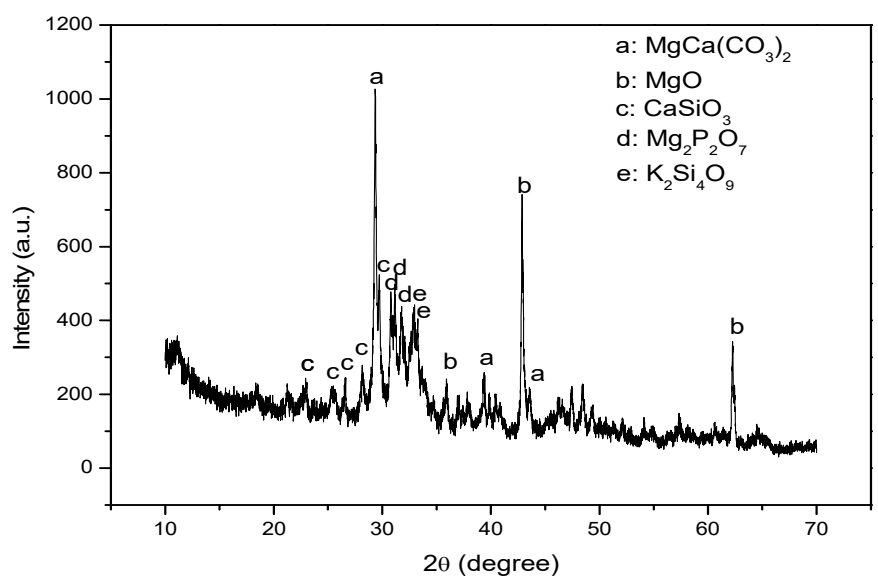

Figure 4: XRD of sunflower husk ashes.

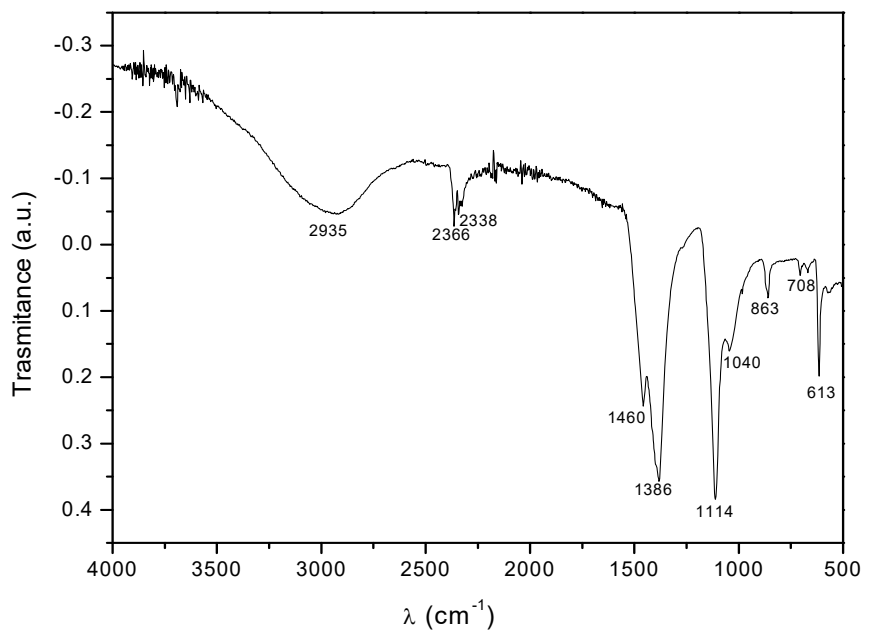

Figure 5: FTIR spectrum of sunflower husk ashes. 
respectively. It is a strongly basic residue. This is an important factor in order to evaluate the possibility of reusing this material as soil filler because it can cause alkalinisation of the area where it is deposited.

The hot water extraction is a very useful practice to determine the elements and compounds potentially removable from the residue and it was used to obtain the soluble solids. Table 2 shows the chemical analysis of the solids obtained expressed as weight percent of its elements. In this table it is possible to see that the major elements that were determined in the chemical analysis of the residue are not present in these solids. Hence the importance of this type of analysis in the study of the feasibility of reusing waste as soil filler. From these results it is possible to estimate the elements and/or compounds that can be solubilised when these are combined with rainwater or subterranean water, producing their transportation to other receptors, for example, rivers, lakes, ponds or other soils.

Table 2: $\quad$ EDS analysis of soluble solids.

\begin{tabular}{|cccccc|}
\hline Element & $\mathrm{O}$ & $\mathrm{Si}$ & $\mathrm{S}$ & $\mathrm{Cl}$ & $\mathrm{K}$ \\
Weight $\%$ & 53.7 & 1.3 & 5.6 & 1.3 & 38.1 \\
\hline
\end{tabular}

The analysis of the leachate liquids of a waste also reflects the possibility that some elements are transferred to soils if it is disposed in landfills, constituting a transfer way to surface water or groundwater. In the leaching test of waste, the results were analysed considering the definitions and limits set out in Regulatory Decree of Law No. 24051 (Argentina) on hazardous waste regime (Decree 831/93). This Decree in the Annex IV identifies a waste as hazardous on the basis of certain characteristics, including leachability. Regarding this characteristic, it provides a list of 25 elements and compounds whose limit concentrations are also detailed. Table 3 shows the values obtained for various analysed elements in the residue and limit values of some of them according to the mentioned law. None of the studied elements exceed the limit values, this would indicate that the ashes of sunflower husk can be used as fillers, to improve routes or to raise land or even

Table 3: Analysis of leaching from the ashes.

\begin{tabular}{|ccc|}
\hline $\begin{array}{c}\text { Element } \\
{[\mathrm{mg} / \mathrm{l}]}\end{array}$ & Ashes & Limit values \\
\hline $\mathrm{Zn}$ & 0.53 & 500 \\
$\mathrm{Cu}$ & $<0.01$ & 100 \\
$\mathrm{~Pb}$ & $<0.01$ & 1 \\
$\mathrm{Cd}$ & $<0.01$ & 0.5 \\
$\mathrm{Ni}$ & 0.026 & 1.34 \\
$\mathrm{Fe}$ & 0.66 & -- \\
$\mathrm{Mn}$ & $<0.01$ & -- \\
$\mathrm{Cr}$ & 0.024 & 5 \\
$\mathrm{Co}$ & $<0.01$ & -- \\
$\mathrm{Al}$ & 0.012 & -- \\
\hline
\end{tabular}


as aggregate in bricks without constituting risks to the environment, i.e. they should not be regarded as hazardous waste.

In this table it is possible to see values of elements such as $\mathrm{Zn}, \mathrm{Ni}, \mathrm{Fe}$ and $\mathrm{Cr}$ which were not detected in the EDS analysis. This is because they are in very small percentages, below the technique detection limit $(0.05 \%)$.

Another important parameter to measure in the case that the residue is used as soil filler or land raiser is the ecotoxicity. This test is performed to evaluate the toxic effect of waste on the seeds germination and seedlings development processes during the first days of growth. At this stage numerous physiological processes occur, in which the presence of a toxic substance, even in such low concentration levels that are not sufficient to inhibit the germination, may interfere altering survival and normal plant development. Figure 6 shows photographs with the influence of residue aqueous extract at concentrations of $25 \%, 50 \%$ and $100 \%$ and the experience carried out with solid residue (ashes). The result of this essay shows that sunflower husk ashes inhibit completely root growth at the concentrations studied, with the exception of the test with $25 \%$ of aqueous extract, where it is possible to observe some radicles and seedlings sprouting (marked by arrows in the picture), although with a high root inhibition index (RI). The adequate plasticity measurement in clay mixtures is very important in order to obtain defect-free products. Atterberg limits are used as reference to determine the plasticity degree of green bodies. Using the Casagrande method it is possible to determine these limits (liquid limit and plastic limit) as well as the plasticity index. With this information it can be predicted the behaviour of the mixtures.

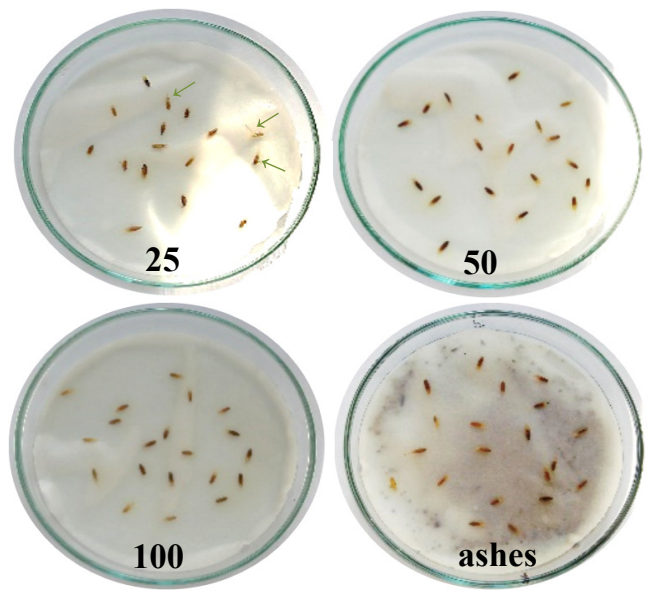

Figure 6: Ecotoxicity analysis of ashes.

The test was performed with mixtures of clay-residue up to $40 \%$ ashes since it was impossible to determine the liquid limit of mixtures with contents greater than $40 \%$ residue.

In Figure 7 a prognostic of the studied mixtures behaviour is shown.

From these tests, it is possible to see that as the percentage of the ashes in the mixtures increases, the plasticity index decreases and the plastic limit slightly 
increases, away from the acceptable extrusion zone. This suggests that for obtaining ceramics pieces from clay-ash mixtures it would be advantageous to use uniaxial pressure in moulds as forming method.

Depending on the chemical composition of the clay and the ashes, and the relationship between them according to the percentages in each mixture, the major oxides were taken to define the ternary equilibrium diagram which best fits. In this case, it turned out to be $\mathrm{SiO}_{2}-\mathrm{Al}_{2} \mathrm{O}_{3}-\mathrm{MgO}$ (Figure 8). Once the mixtures with

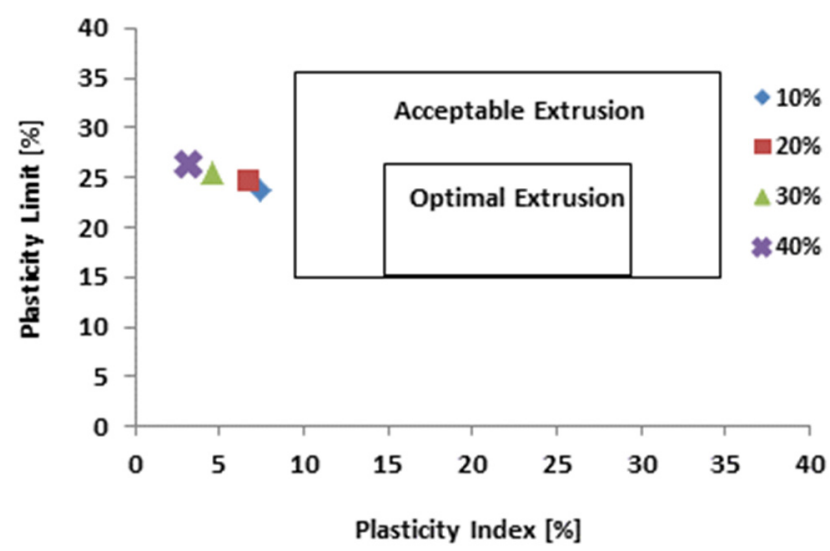

Figure 7: Behaviour prognostic of clay-ashes mixtures.

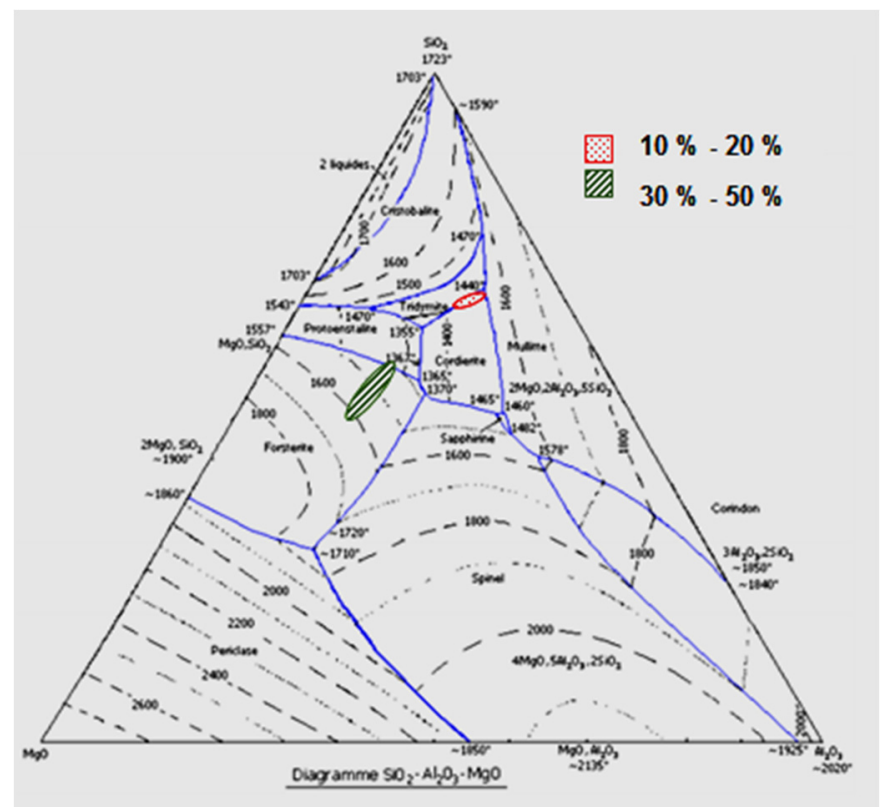

Figure 8: Ternary equilibrium diagram $\mathrm{SiO}_{2}-\mathrm{Al}_{2} \mathrm{O}_{3}-\mathrm{MgO}$. 
aggregate ashes until $50 \%$ were located into the diagram, it can be seen that the compositions below $20 \%$ are within the compatibility triangle defined by silica, cordierite and mullite, where the temperature of the first formation of liquid is approximately $1400^{\circ} \mathrm{C}$. Therefore, the probable sintering temperature (calculated as $75 \%$ from above), would be approximately $1050^{\circ} \mathrm{C}$. In contrast, for compositions with higher percentages of residue, the temperature of first formation of liquid would be $1700^{\circ} \mathrm{C}$, with probable sintering temperature of $1275^{\circ} \mathrm{C}$. Figure 8 shows the equilibrium diagram with the location of the different compositions used in the calculations.

\section{Conclusions}

According to the results obtained from the analysis of leachate and soluble solids, the studied residue, ashes from sunflower husks, would be suitable for use as soil filler or land raiser, or it can be deposited in landfills, since it does not exceed the limit values of leachability and the elements found in the soluble solids are not dangerous for the environment. However, taking into account the results of $\mathrm{pH}$ and ecotoxicity, the studied residue is strongly alkaline and its presence affects the establishment and development of certain vegetable species negatively.

About the feasibility of reusing this waste as aggregate in clay mixtures for ceramic products, the addition of sunflower husk ashes decreases the clay plasticity, indicating that the pressure forming method is preferable instead of the extrusion method to obtain the green pieces.

The study of ternary phase diagrams for determining probable sintering temperatures of ash-clay mixtures shows that it is possible to incorporate until to $20 \%$ of waste maintaining processing temperatures commonly used in the ceramic industry $\left(1050^{\circ} \mathrm{C}\right)$. For higher percentages, the sintering temperatures of compacts increase considerably making this incorporation difficult and costly.

\section{Acknowledgements}

The authors thank the National Agency for Scientific and Technological Promotion (ANPCyT) and Scientific Investigations Commission of the Buenos Aires Province (CIC) for the financial support received.

\section{References}

[1] N. Quaranta, M. Unsen, H. López, C. Giansiracusa, J. Roethert, A. Boccaccini. "Ash from sunflower husk as raw material for ceramic products". Ceramics International 37 pp. 377-385, 2011.

[2] L. Pérez-Villarejo, D. Eliche-Quesada, F. Iglesias-Godino, C. MartínezGarcía, F. Corpas-Iglesias. "Recycling of ash from biomass incinerator in clay matrix to produce ceramic bricks". Journal of Environmental Management 95 pp. 349-354, 2012. 
[3] S. Teixeira, R. Magalhães, A. Arenales, A. Souza, M. Romero, J. Rincón. "Valorization of sugarcane bagasse ash: Producing glass-ceramic materials". Journal of Environmental Management 134 pp. 15-19, 2014.

[4] C. Fernández-Pereira, J. de la Casa, A. Gómez-Barea, F. Arroyo, C. Leiva, Y. Luna. "Application of biomass gasification fly ash for brick manufacturing". Fuel 90 pp. 220-232, 2011.

[5] J. Cuenca, J. Rodríguez, M. Martín-Morales, Z. Sánchez-Roldán, M. Zamorano. "Effects of olive residue biomass fly ash as filler in selfcompacting concrete". Construction and Building Materials 40 pp. 702 709, 2013.

[6] B. Carrasco-Hurtado, F.A. Corpas-Iglesias, N. Cruz-Pérez, J. TerradosCepeda, L. Pérez-Villarejo. "Addition of bottom ash from biomass in calcium silicate masonry units for use as construction material with thermal insulating properties". Construction and Building Materials 52 pp. 155-165, 2014.

[7] R. Modolo, V. Ferreira, L. Tarelho, J. Labrincha, L. Senff, L. Silva. "Mortar formulations with bottom ash from biomass combustion". Construction and Building Materials 45 pp. 275-281, 2013.

[8] S. Demis, J. Tapali, V. Papadakis. "An investigation of the effectiveness of the utilization of biomass ashes as pozzolanic materials". Construction and Building Materials 68 pp. 291-300, 2014.

[9] R. Melotti, E. Santagata, M. Bassani, M. Salvo, S. Rizzo. "A preliminary investigation into the physical and chemical properties of biomass ashes used as aggregate fillers for bituminous mixtures". Waste Management 33 pp. 1906-1917, 2013.

[10] E.A. Basha, R. Hashim, H. Mahmud, A. Muntohar. "Stabilization of residual soil with rice husk ash and cement". Construction and Building Materials. 19 pp. 448-453, 2005.

[11] D. Vamvuka, E. Kakaras. "Ash properties and environmental impact of various biomass and coal fuels and their blends". Fuel Processing Technology 92 pp. 570-581, 2011.

[12] R. Palackiene, A. Sviklas, R. Slinksiene, V. Streimikis. "Complex fertilizers produced from the sunflower husk ash". Polish Journal of Environmental Studies 19(5) pp. 973-979, 2010. 